NBER WORKING PAPER SERIES

\title{
OFFSHORE INVESTMENT FUNDS: \\ MONSTERS IN EMERGING MARKETS?
}

\author{
Woochan Kim \\ Shang-Jin Wei
}

Working Paper 7133

http://www.nber.org/papers/w7133

\author{
NATIONAL BUREAU OF ECONOMIC RESEARCH \\ 1050 Massachusetts Avenue \\ Cambridge, MA 02138 \\ May 1999
}

We thank Chul-Hee Park for the data and the OECD Development Center for partial financial support through its program on international capital flows (Head of Research, Helmut Reisen), Richard Zeckhauser and seminar participants at Harvard University and Brandeis University for helpful comments, and Greg Dorchak for editorial assistance. The views expressed herein are those of the authors and do not necessarily reflect the views of the National Bureau of Economic Research or any other organization with which they are or have been affiliated.

(C) 1999 by Woochan Kim and Shang-Jin Wei. All rights reserved. Short sections of text, not to exceed two paragraphs, may be quoted without explicit permission provided that full credit, including ${ }^{\circledR}$ notice, is given to the source. 
Offshore Invesment Funds: Monsters in Emerging Markets?

Woochan Kim and Shang-Jin Wei

NBER Working Paper No. 7133

May 1999

JEL No. F21, F3, G15

ABSTRACT

The 1997-99 financial crises in the emerging markets have brought to the foreground the concern about offshore investment funds and their possible role in exacerbating volatility in the markets they invest in. Offshore investment funds are alleged to engage in trading behaviors that are different from their onshore counterparts. Because their behavior is less moderated by tax consequences, and because they may be subject to less supervision and regulation, the offshore funds may trade more intensely. They could also pursue more aggressively certain trading strategies such as positive feedback trading or herding that could contribute to greater volatility in the market.

Using a unique data set, we compare the trading behavior in Korea by offshore funds with that of their onshore counterparts registered in the United States and the United Kingdom. There are a number of interesting findings. First there is indeed evidence suggesting that the offshore funds trade more intensely than their onshore counterparts. Second, however, there is no eviùence that the offshore funds engage in positive feedback trading. In contrast, there is strong evidence that the funds from the US and UK do so. Third, while offshore funds herd, they do so significantly less than the offshore funds from the US or UK. In sum, the offshore funds are not especially worrisome monsters.

Woochan Kim

Kennedy School of Government Harvard University

79 JFK Street

Cambridge, MA 02138

kimwooc@ksg.harvard.edu
Shang-Jin Wei

Kennedy School of Government Harvard University

79 JFK Street

Cambridge, MA 02138

and NBER

shang-jin@wei@harvard.edu 


\section{Introduction}

The 1997-99 financial crises in the emerging markets have brought to the foreground the concern about offshore investment funds and their possible role in exacerbating volatility in the markets they invest in. Offshore funds are collective investment funds registered in tax havens, typically small islands in the Caribbean, Europe and Asia Pacific. The host countries/territories not only do not tax the funds, they typically do not forward the financial information to other tax and financial authorities. Furthermore, the regulation on these funds in the tax havens is often less stringent than that of major industrialized countries where most of the onshore investment funds are located. Helm (1997, p414) listed seven areas in which offshore funds face less regulations as compared with their counterparts in the U.S. For example, offshore funds would have greater flexibility and less procedural delays in changing the nature, structure, or operation of their products, and they would face fewer investment restrictions, short-term trading limitations, capital structure requirements, governance provisions, and restrictions on performance-based fees.

As a consequence, offshore funds may engage in trading behaviors that are different from their onshore counterparts. For example, it has been alleged that foreign portfolio investors may engage in positive feedback trading (e.g., rushing to buy when the market is booming and rushing to sell when the market is declining), and eager to mimic each other's behavior while ignoring information about the fundamentals. There is a concern that offshore funds may be more prone to this kind of trading pattern than their onshore counterparts either due to the nature of their investment styles or due to lower regulatory constraints they face at home. Behaviors such as these by offshore funds could exacerbate a financial crisis in a country to an extent not otherwise warranted by economic fundamentals.

A better understanding of the offshore funds' behavior is highly relevant for the renewed debate on capital controls on short-term portfolio capital flows. Aside from outright capital controls imposed by capital receiving countries, one may imagine better supervision and risk regulation by the governments of the capital-exporting countries as another way to regulate international capital flows. Indeed, many may prefer this 
approach to outright capital controls imposed by capital-importing countries. However, the presence of offshore funds adds challenges to this approach. Even when the G7 governments can agree on a particular regulatory structure, it may not apply to the offshore centers. Moreover, many currently onshore funds could migrate offshore as a result of changes in the regulations in their onshore domiciles.

The hypothesis that offshore funds may pursue destabilizing trading strategies can be connected with an emerging literature on behavioral finance, mostly in the domestic finance context. For example, using evidence from domestic market data, it has been argued that institutional investors often exhibit herding behavior, though the tendency is quantitatively small (see Lakonishok, Shleifer and Vishny, 1992). There are also theoretical models in which rational investors may pursue positive feedback strategies, destabilizing prices in the process (De Long, Shleifer, Summers, and Waldmann, 1990).

A number of authors have empirically examined the behavior of foreign investors in emerging markets. They include Frankel and Schmukler $(1996,1998)$, who have investigated closed-end country funds; Choe, Kho, Stulz (1998), who have examined the effects of foreign investor as a whole on the Korean stock prices; Froot, O'Connell and Seasholes (1998) who have examined the aggregate portfolio flows into various countries; and Kim and Wei (1999), who have looked into the differences as well as similarities in trading behavior between individual versus institutional foreign investors, and foreign investors who reside in Korea versus those outside. None of these papers has compared the behavior between offshore and onshore funds.

Fung and Hsieh (1997), Brown, Goetzmann and Ibbotson (1999) and Brown Goetzmann and Park (1999) pioneered the examination of trading strategies of hedge funds, many of them located offshore. They find that hedge funds appear to shift weights on different assets very frequently. The last paper finds that the currency hedge funds were unlikely to have triggered the Asian currency crisis. Lacking the data on actual position holdings of the funds, these papers utilize return information to infer trading strategies a la Sharpe's (1992) style analysis. This is clever and very useful, but there can be errors if certain assets that the funds have actually traded on are not included in the analysis by the econometricians, and the omitted and included assets have correlated returns. 
In this paper, we utilize a unique data set on actual month-end trading positions of foreign funds in Korea to study the behavior of offshore funds. To put the results in context, we compare them with those funds that are registered in the United States and United Kingdom (and also Singapore and Hong Kong as a supplementary group), where the relevant regulations and regulators are among the most respected in the world ${ }^{1}$, and where most onshore funds are located. The Singapore and Hong Kong make a useful comparison group because they, like the offshore centers, do not tax capital gains. The data covers the period from the end of 1996 to June 30, 1998, which allows us to see if the behavior of the funds changes during a financial crisis.

It is useful to note that the effect of foreign investors as a group was found to be small on the Korean market volatility in 1997 in part because foreign investors were not a large part of the market (Choe, Kho, Stulz, 1998). We still would want to know if the offshore funds engage in trading patterns potentially more destabilizing than their onshore counterparts. If the answer is yes, then, in markets where they have a larger presence (that is, in smaller and/or more open markets thanKorea in 1997 which may include Korea itself in the future), they could still contribute to the market volatility in a significant way.

The paper is organized as follows. Section 2 describes our data sets. Sections 3, 4 , and 5 examine three aspects of foreign investor behavior, respectively: turnover, feedback trading, and herding. Section 6 offers some concluding remarks.

\section{Data}

Offshore and onshore funds and their positions

Our investor position data set identifies each foreign investor by a unique ID code, and reports the domicile of each fund, and its month-end holding of every stock listed in the Korean stock exchange. Our sample covers the period from the end of 1996

\footnotetext{
' In a survey firms reported by the Global Competitiveness Report 1998 (World Economic Forum, 1998), the respondents were asked to rate the perceived adequacy of financial regulation. On a 1 (least adequate) to 7 (most adequate) scale, the United States and United Kingdom received an average of 6.53 and 6.36 scores, respectively. Both of them are among the top five most adequate countries among the 53 countries covered in the sample. In addition, Singapore and Hong Kong (with the scores of 6.29 and 5.72, respectively) are also among the top fifteen countries in the country in terms of adequate regulations of
} 
to June 30,1998 . This proprietary data set was kindly provided to us by the Korea Securities Computer Corporation (KOSCOM), an affiliate to the Korea Stock Exchange (KSE).

Our set of offshore funds are mutual funds or unit trusts that report their domicile to the Korean government as either Bahamas, Bermuda, Cayman Islands, Channel Islands, Guernsey, Jersey, Liechtenstein, Panama, or the British Virgin Islands. There are 77 such funds that own some stocks at least sometime during the sample. It is interesting to note that almost every single such domicile has a current or historical Anglo-Saxon connection. According to anecdotal evidence, many of the investors in the offshore funds are current or past nationals of the United States, United Kingdom or other G7 countries.

For comparison, we also look at mutual funds or unit trusts that are registered in the United States and United Kingdom (as a group), two largest homes of the onshore investment funds, and those in Singapore and Hong Kong (as another group). All of the four have well-regarded securities and mutual fund laws and competent regulatory agencies. There are a maximum of 783 funds in the US/UK group, and 36 funds in the Singapore/HK group in the sample.

We exclude funds from many other domiciles such as Luxembourg from the analysis because we cannot separate offshore from onshore funds registered in the same country. We also exclude pension funds, commercial banks, investment banks, or insurance companies from our analysis, because none of them active in Korea except for one commercial bank comes from an offshore center on our list.

Table 1 reports the number of funds in each category. We see that the average position of an offshore fund in Korea is a lot smaller than the average of an American or British fund, though slightly larger than that of a Singapore or Hong Kong fund. There is no category labeled as hedge funds in our sample. Our understanding from communicating with KOSCOM is that they would register themselves either as mutual funds, unit trusts, or as "others". Notice that a hedge fund can either be an onshore or offshore fund. Our presumption would be that a greater fraction of the funds from our offshore group are hedge funds or pursue hedge-fund-like strategies than those from the U.S. and U.K. 
The position data by investor and by stock is hard to come by in general. In our case, the Korean government's restriction on foreign ownership of Korean stocks and the need to enforce it helps to make this data available. ${ }^{2}$

\section{Stock Data}

For each stock, we collect information on (i) month-end price, (ii) month-end number of shares outstanding, and (iii) whether the investment ceiling is binding in that month. In addition, we also collect information on the Korea Composite Stock Price Index (KOSPI) from KOSCOM and month-end Won/dollar exchange rate from the Federal Reserve Board's website ${ }^{3}$.

Figures 1 and 2 plot the exchange rate (US dollar/1,000 Won) and the stock market price index (KOSPI), respectively. Combining the two pieces of information, Figure 3 traces the dollar value of a $\$ 100$ investment in KOSPI on January 1, 1997 throughout the sample (to June 30, 1998).

November 1997 was the month when the foreign exchange crisis occurred in Korea. On November 18, the Bank of Korea gave up defending the Korean Won. And on November 21, the Korean government asked the IMF for a bail out. In some of our analyses, we break the sample into two: a pre-crisis period before and including October 1997 (ten months in our sample), and an in-crisis period from November 1997 to June 1998.

\section{Intensity of Trading}

Not having to pay capital gains tax, and facing less supervision and regulation from home governments may induce offshore funds to trade more intensively than their

\footnotetext{
${ }^{2}$ For example, between May and November 1997, foreign investors, in aggregate, could not own more than $23 \%$ of the outstanding shares per company and foreign investors, individually, could not own more than 6\%. Since May 1998, there exists no restriction on foreign ownership, except for 42 listings on KSE and 6 on KOSDAQ. Upper ceiling on foreign investors in aggregate changed from $10 \%$ (Jan, 1992) $\rightarrow 12 \%$ (Dec, $1994) \rightarrow 15 \%(\mathrm{Jul}, 1995) \rightarrow 18 \%(\mathrm{Apr}, 1996) \rightarrow 20 \%($ Oct, 1996) $\rightarrow 23 \%$ (May, 1997) $\rightarrow 26 \%$ (Nov, $1997) \rightarrow 55 \%$ (Dec, 1997) $\rightarrow$ 100\% (May, 1998). As for individual foreign investor, the upper ceiling changed from 3\% (Jan, 1992) $\rightarrow 4 \%($ Apr, 1996) $\rightarrow 5 \%$ (Oct, 1996) $\rightarrow 6 \%$ (May, 1997) $\rightarrow 7 \%$ (Nov, $1997) \rightarrow 50 \%$ (Dec, 1997) $\rightarrow 100 \%$ (May, 1998).
} 
onshore counterparts ${ }^{4}$. In addition, investment funds that prefer to trade more actively may self-select to locate in the offshore centers.

In this section, we examine whether offshore funds actually trade more intensely or not. Because our data does not record within-month transactions, we cannot compute an accurate measure of turnover. However, we observe the total changes in the weights allocated to different stocks on a monthly basis. Our presumption is that, across investor groups, the total changes in the month-to-month weights are highly correlated with the true turnovers. We will use the term "trading intensity" in subsequent discussions to denote the changes in the weights on all the stocks.

Let $w(j, k, t)$ denote the market value of the position in stock $k$ held by investor $j$ at the end of month $t$, divided by the total value of all stocks held by the same investor at the same time. We compute the sum of the absolute values of the changes in the weights across all stocks for investor $\mathrm{j}$ at time $\mathrm{t}$ using the following definition:

$$
T N(j, t)=\sum_{k}|w(j, k, t)-w(j, k, t-1)|
$$

The average trading intensity (weight changes) for investor $\mathrm{j}$ defined as:

$$
T N(j)=\frac{1}{T-1} \sum_{t=2}^{T} T N(j, t)
$$

where $\mathrm{T}$ is the total number of months in the sample. The average trading intensity for investors in a given group is then the average of all TN(j) over investor $\mathrm{j}$ in the group $\mathrm{i}$ (subscript-i omitted):

$$
T N=\frac{1}{J} \sum_{j} T N(j)
$$

Under the central limit theory, the TN measure is asymptotically normal.

Panel A of Table 2 reports, for each of the three groups of the funds, the trading intensity measured in this way. For the whole sample, we see that the average trading

\footnotetext{
${ }^{3}$ www.bog.frb.fed.us/release/H10/hist/

${ }^{4}$ While the offshore funds may not pay taxes in their domiciles, they may still need to pay taxes in Korea, in particular, $25 \%$ withholding tax on dividend and interest, and $10 \%$ of the gross proceeds realized from the sale for capital gains. In cases where the purchasing price is available, the tax is the lesser of $25 \%$ of the capital gains and $10 \%$ of the gross proceeds. See the Korea Stock Exchange Website, www.kse.org/kr/stat/index.html. These tax rates are typically lower than what the onshore funds have to pay to their home taxing authorities.
} 
intensity for the offshore funds is $45 \%$ bigger than that for the US/UK funds. Using a difference-in-mean test, we can see that the difference between the two is statistically significant at the five percent level (Column 4). On the other hand, the offshore funds' trading intensity is not statistically different from the Singapore/Hong Kong funds (Column 5).

If we break the sample into pre-crisis and in-crisis sub-periods, we see an interesting pattern. The average trading intensity increases for each of the three groups of funds in the crisis period relative to the pre-crisis period (and significant for the US/UK funds). The offshore funds' average trading intensity continues to be bigger than the onshore funds from the US/UK.

As a robustness check, we also experiment with defining the trading intensity in terms of the physical shares of stocks instead of the market value of the stocks. To be more precise, we let $w(j, k, t)$ be the number of stock $k$ held by investor $j$ at the end of month $t$, divided by the total number of all stocks that she held at the same time. Then, TN(j) and TN are defined in the same way as before. The results are reported in Panel B of Table 2. We can see clearly that all the qualitative results from Panel A remain to be true here. Thus, the offshore funds do trade more intensely than onshore funds (from the US and UK) both before the crisis, and even more so during the crisis.

\section{Positive Feedback Trading}

There are concerns that offshore funds may engage in positive-feedback trading more aggressively than onshore funds, and that positive feedback trading could destabilize the market. Positive feedback trading pattern is when one buys securities when the prices rise and sells when the prices fall. This trading pattern can result from extrapolative expectations about prices, from stop-loss orders --automatically selling when the price falls below a certain point, from forced liquidations when an investor is unable to meet her margin calls, or from a portfolio insurance investment strategy which calls for selling a stock when the price falls and buying it when the price rises.

Positive feedback trading can destabilize the market by moving asset prices away from the fundamentals. At least since Friedman (1953), many economists believe that 
positive feedback traders cannot be important in market equilibrium as they are likely to lose money on average. This view has been challenged in the last decade or so. De Long, Shleifer, Summers, and Waldmann (1990) argued that in the presence of noise traders, even rational investors may want to engage in positive feedback trading, and in the process destabilize the market.

Empirical examination of this issue has emerged recently. Using quarterly data on U.S. pension funds in the U.S. market, Lakonishok, Shleifer, and Vishny (1992, LSV for short in later reference) did not find strong evidence of significant feedback trading. On the other hand, and Grinblatt, Titman and Wermers (1995) did find evidence of positive feedback trading with their sample of 274 US mutual funds during 1975-1984. Using transaction-level data, Choe, Kho, and Stulz (1998) also find evidence that foreign investors as a group engage in positive feedback trading in Korea. No paper that we are aware of compares the positive trading tendencies of offshore versus onshore trading strategies.

\section{Methodology}

The objective is to examine the connection between the trading behaviors of the investors (within a given sub-group) and the previous month performance of the stocks. We examine the connection for three time periods: the whole sample (January, 1997 June, 1998), the pre-crisis period (January, 1997-October, 1997), and the in-crisis period (November, 1997-June, 1998).

Within each time period, we form five approximately equally sized (in terms of stock-months) portfolios based on the previous month performance of the stocks. The performance of a stock is defined as the return of the stock in excess of the market return, minus the depreciation of the Korean won exchange rate against the U.S. dollar. That is, the return for a particular stock from month t-1 to month $\mathrm{t}$ is $\left[\ln \left(P_{\nu}\right)-\ln \left(P_{t-1}\right)\right]$ $\left[\ln \left(K O S P I_{\downarrow}\right)-\ln \left(K O S P I_{t-1}\right)\right]-\left[\ln \left(S_{\downarrow}\right)-\ln \left(S_{t-1}\right)\right]$, where $P_{t}, K O S P I_{t}$, and $S_{t}$ are the price of the stock (stock subscript omitted), KOSPI index, and Won/\$ exchange rate at time $t$.

Following Lakonishok, Shleifer and Vishny (1992), we employ two measures of investors' trading direction: a buyers' ratio and a scale-adjusted net purchase: 


$$
\text { Buyers' Ratio }=\frac{\text { Number of Buyers }}{\text { Number of Buyers }+ \text { Number of Sellers }}
$$

(2) Scale - adjusted Net Purchase $=\frac{\text { Number of Shares Purchased }- \text { Number of Shares Sold }}{\text { Number of Shares Purchased }+ \text { Number of Shares Sold }}$

The first measure describes the fraction of active traders that is a net buyer. It is constructed to minimize the dominance of a few large traders in the statistics. The second measure describes the net purchase (scaled by the total trading). The denominator (the scale adjustment) makes sure that a large purchase does not receive more weight than a small purchase

To avoid possible biases in quantifying the trading behavior, we exclude certain observations (investors or stock-month). First, investors who are registered after December 31, 1996 are dropped because their entrance to the market could show up only as a buy. Second, stock-months for which a stock has reached the foreign ownership limit are dropped because any change in the net position of the foreign investors as a whole has to be a sell to Korean investors.

\section{Results and Interpretations}

Table 3 reports the basic finding using buyer's ratio as a measure of trading direction. Let us look at the US/UK funds first. For the entire sample period (97.1-98.6) (reported in Column 4 of the top panel), 39\% of active traders buy the worst performing stocks (in terms of last month returns), compared to more than $50 \%$ of active traders who buy the recent best performing stocks. Indeed, in the sixth row, we report a formal t-test on difference between the two buyers' ratios. The standard errors are reported in parenthesis ${ }^{5}$. We see the difference is positive and statistically significant. This is consistent with the view the US/UK funds are positive feedback traders.

In contrast, for the offshore funds (reported in Column 3), the buyer's ratios for the recent worst and best performing stocks are $41 \%$ and $46 \%$, respectively. The difference between the two ratios is smaller than for the US/UK funds. In fact, a formal t-

\footnotetext{
${ }^{5}$ The same reporting format is used for all sub-groups of investors in all time periods.
} 
test indicates that the difference is not statistically significant at the ten percent level ${ }^{6}$. The same is true for funds from Singapore/Hong Kong.

When we look into pre- and in-crisis sub-samples (middle and lower panels of Table 3), we see that the propensity to engage in positive feedback trading by American and British funds is stronger during the crisis than before it. There is still no statistically significant evidence that offshore funds engage in positive feedback trading.

In Table 4, we use the scale-adjusted net purchase as an alternative measure of trading patterns. Onshore funds from the US and UK sell recent losers more aggressively than recent winners, a pattern consistent with positive feedback trading. In comparison, the offshore funds do not exhibit statistically significant difference in the net purchase of the recent worst and best performing stocks. Hence, we reach the same qualitative conclusion as before: no evidence to support the hypothesis that offshore funds engage in positive feedback trading more aggressively than onshore funds from the US or UK. If anything, the contrary is true.

In Table 5, we decompose the stocks along a second dimension, the market capitalization at the beginning of the month, into small, medium and large stocks. So within a sample period, the stocks are now classified into nine categories. We observe that the offshore funds tend to hold mostly medium and large stocks relative to the U.S./UK funds. Moreover, for the US/UK funds, the positive feedback trading pattern is most visible for large stocks in the pre-crisis period, but most visible for small or medium stocks during the crisis.

A possible defense of positive feedback trading is that foreign investors (residing abroad) may be informationally disadvantaged relative to domestic investors. They may take a (relatively greater) decline in the price of a particular stock as unfavorable news revealed by domestic investors, and may therefore rationally choose to sell it (more aggressively relative to other stocks) (See Brennan and Cao, 1997, for such a model). It may be useful to check if the positive-feedback-trading pattern in our sample is ex post profitable. We do it in two steps. First, in each month, we form an equally-weighted

\footnotetext{
${ }^{6}$ Of course, the buyers' ratio is not strictly monotonic in past returns. So for example, the difference between those of the best and median performing portfolios is statistically significant. But one would not characterize the offshore funds as positive feedback traders since the buyers' ratio is U-shaped as a function of past returns.
} 
portfolio of ten best performing stocks, and another equally-weighted portfolio of ten worst performing stocks, based on the previous month's return as defined above for Tables 3 and 4.

The average returns of the two portfolios in the previous months are reported in the first row of each of the three panels (representing three different periods) in Table 6 (labeled as "horizon -1"). Second, we track their performances over the subsequent six months. The results are reported in the other rows of Table 6 (labeled as "horizons 16"). We perform a difference in mean test (mean return of the past winners minus that of the past losers) and find that the difference is negative for all six horizons under investigation. The difference is statistically significant for the one- to five-month horizons at the ten percent level. In other words, the data suggest that the relative ranking of stock performance reverses itself in the sample. On average, if one has to choose between a negative and a positive feedback trading strategy, the former would have been superior, at least at the one- or two-month horizon. The excess return is quantitatively large at $8 \%$ monthly rate. Of course, in this down market, selling both the best and worst performing portfolios would be ex post more profitable (and one should sell recent winners more aggressively).

As a robustness check, we also form equally weighted portfolios of 30 best performing and 30 worst performing (based on previous-month's returns) stocks. The results are reported in the right half of Table 6 . For these enlarged portfolios, again, there is reversal in the ranking of relative performance. In fact, the recent past losers outperform the recent winners, in a statistically significant and quantitatively large way, over one-month, two-month, and so on, all the way to five-month horizons. Again, a contrarian trading strategy rather than a positive feedback one would have been profitable.

As qualifications, we note that our thought experiments have not adjusted for risk levels of the stocks, and do not preclude the possibility that a positive feedback trading strategy could be profitable within a day or for horizons longer than six months. 


\section{Correlated Trading}

Herding is the tendency that investors of a particular group mimic each other's trading. Portfolio investors may herd rationally or irrationally. Informational asymmetry may cause uninformed but rational speculators to choose to trade in the same way as informed traders (Bikhchandani, Hirshleifer and Welch, 1992; and Banerjee, 1992). Since informational problem may be more serious when it comes to investing in a foreign market than the domestic one, herding may be more severe correspondingly. Whether offshore funds herd more or less than the onshore funds depends on their relative capacity in collecting and processing information about the emerging market in question.

There is an alternative explanation for herding among institutional investors. Unlike individual investors, fund managers face regular reviews (e.g., quarterly for mutual funds, and annually for pension funds) on their performance relative to a benchmark and/or to each other. This may induce them to mimic each other's trading to a greater extent than they otherwise would (See Scharfstein and Stein, 1990). By this logic, whether the offshore funds herd more or less than the onshore funds depends on whether informational asymmetry is greater or less for them. By this logic, there might be less herding among offshore funds if they are subject to either fewer or less frequent performance reviews.

There have been several empirical papers that quantify herding behavior. Using data on institutional investors, the pioneering paper by Lakonishok, Shleifer, and Vishny (or LSV, 1992), followed by Grinblatt, Titman, and Wermers (1995), and Wylie (1997), all report evidence of herding among US or UK institutional investors. Using data on foreign investors (or U.S. investors) in Korea as a single group, Choe, Kho, and Stulz (1998) find evidence of herding. None of the previous papers that we are aware of compares different herding tendencies by different investor types on data from a single source, which is the central focus of this section of our paper.

\section{Methodology}

We employ the herding index measure proposed by LSV (1992). While we refer to the LSV measure as herding index as they do, it is useful to remember that what it 
measures is the correlation in trading patterns among members of a group (the tendency to which investors buy or sell the same subset of stocks). Obviously, herding leads to correlated trading, but the reverse may not be true.

Let $B(i, j, t)$ be the number of investors in group $i$ that have increased the holdings of stock $j$ in month $t$ (i.e., number of net buyers), and $S(i, j, t)$ the number of investors in group $i$ that have decreased the holdings of stock $j$ in month $t$ (number of net sellers). Let $p(i, t)$ be the number of net buyers in group $i$ aggregated across all stocks in month $t$ divided by the total number of active traders (number of net buyers plus number of net sellers) in group $i$ aggregated across all stocks in month $t$. Then, $H(i, j, t)$ is defined as the herding index for investors in group $\mathrm{i}$, on stock $j$, in month $t$.

$$
H(i, j, t)=\left|\frac{B(i, j, t)}{B(i, j, t)+S(i, j, t)}-p(i, t)\right|-E\left|\frac{B(i, j, t)}{B(i, j, t)+S(i, j, t)}-p(i, t)\right|
$$$$
p(i, t)=\frac{\sum_{j=1}^{N} B(i, j, t)}{\sum_{j=1}^{N} B(i, j, t)+\sum_{j=1}^{N} S(i, j, t)}
$$

(3) $\quad H(i, t)=\frac{1}{N} \sum_{j=1}^{N} H(i, j, t)$

(4) $\quad H(i)=\frac{1}{N T} \sum_{i=1}^{T} \sum_{j=1}^{N} H(i, j, t)$

$H(i, t)$ is the herding index for group $i$ in month $t$, averaged across all stocks. $H(i)$ is the herding index for group $\mathrm{i}$, averaged across all months in the sample. In the definition of $\mathrm{H}(\mathrm{i}, \mathrm{j}, \mathrm{t}), p(i, t)$ is subtracted to make sure that the resulting index is insensitive to general market conditions (i.e., a bull or bear market). By taking absolute values, the first term in equation (1) captures how much of the investment is polarized in the direction of either buying or selling. The second term in equation (1), also called as adjustment factor, is subtracted to correct for the mean value of the first term under the assumption of no herding. The second term can be computed under the assumption that 
$B(i, j, t)$ follows a binomial distribution. Note that for large $\mathrm{N}$ and $\mathrm{T}, H(i, t)$ and $H(i)$ follow normal distributions by the central limit theorem.

To avoid any possible bias in computing the herding indices, we exclude certain investors and observations (stock-month) from our sample. Like the sample we have constructed to examine positive feedback trading, we exclude here (1) investors that are registered after December 31, 1996, (2) stock-months for which the foreign ownership limit is reached, and (3) stock-months for which the stocks are not owned by foreign investors in the previous month. The last exclusion is motivated by the short-selling constraint. When short selling is not allowed, any trade on that stock would have to first show up as a buy, thus biasing the herding index upward (Wylie, 1997). Finally, if a stock in a given month is traded by only one foreign investor in that group, that observation is dropped.

\title{
$\underline{\text { Results and Interpretations }}$
}

The basic results are presented in Table 7a. For each investor group $i$ and sample period, we report the corresponding herding statistics, $\mathrm{H}(\mathrm{i})$, with standard errors in the parenthesis below. Then we perform a sequence of difference-in-mean tests between offshore and onshore funds (reported in Columns 4 and 5), and between pre-crisis and incrisis periods for any given group of investors (reported in Row 4).

\begin{abstract}
as The most important findings are the following. First, for both offshore funds as well onshore funds from the US and UK, their positive herding statistics are statistically significant. The only possible exception is the set of funds from Singapore and Hong Kong. Second, most importantly, the evidence suggests that, to the extent investment funds herd, the US/UK funds herd significantly more than their offshore counterparts (for the whole sample and for the pre-crisis period).
\end{abstract}

One may worry that a firm that issues new stocks or buys back its stocks could artificially inflate the herding measure even there is no herding. In Table $7 \mathrm{~b}$, we drop all the observations that involve changes in the quantity of outstanding shares ${ }^{7}$. We find

\footnotetext{
${ }^{7}$ There were 601 occasions (stock-months) on which the outstanding shares increased, and 2 occasions on which the outstanding shares declined.
} 
that, aside from some minor differences, the results we have reached from Table $7 \mathrm{~b}$ are essentially the same as those in Table 7a.

\section{Expost Profitability}

What we label as "herding statistics" (following LSV, 1992) is actually a measure of correlated trading. A bigger value of the "herding" measure for the US/UK funds could result from the fact that they are more likely to respond to common signals than the offshore funds. In other words, the herding measures do not distinguish between two possibilities: that investors intentionally (rationally or not) mimic each other's trading, versus that investors respond to common information about the fundamentals.

To distinguish between the two is difficult which is probably why previous empirical papers do not do this. We decide to provide some suggestive evidence here by examining ex post rationality of the herding behavior in our sample. Under the joint hypotheses that the funds respond to common signals and that the signals are payoffrelevant, we would expect that those stocks that the investors herd more aggressively should yield abnormal returns (relative to those stocks they do not herd as much).

Let $R_{k+1}$ denote the return of stock $j$ from $t$ to $t+1$ in excess of the KOSPI return minus the won exchange rate depreciation. Let $H_{k}$ denote LSV herding index for stock $j$ in month $t$, and $N P_{j}$ the (scale-adjusted) net purchase of stock $j$ in month $t$. All three variables are defined for a given investor group, $i$, which we omit from the subscripts for simplicity. For each investor group, we run the following fixed effects regression:

$$
R_{\mu+1}=\alpha+\alpha_{t}+\alpha_{k}+\left(\beta_{0}+\beta_{1} H_{\mu}\right) N P_{\mu}+\varepsilon_{\mu}
$$

where $\alpha_{t}$ and $\alpha_{2}$ are time and industry dummies ${ }^{8}$. If those stocks that the funds herd to buy appreciate faster than others, and/or if those that the funds herd to sell depreciate faster than others, we would expect $\beta_{1}$ to be positive. We perform this regression for

\footnotetext{
${ }^{8}$ Due to computer capacity constraint, we use 67 industry dummies instead of over 600 stock dummies
} 
both the one-month and three-month investment horizons. The results are reported in Table 8.

In overwhelming number of groups, we see that the estimates of $\beta_{1}$ are not different from zero, and in the two instances when they are significant, they have a negative sign. This is true for both the one-month and three-month horizons. Hence, the joint hypotheses are rejected.

\section{Concluding Remarks}

In this paper, we study the behavior of offshore investment funds as compared with their onshore counterparts in the US, UK, Singapore and Hong Kong. This is made possible by a unique data set that details the monthly stock positions of foreign investors.

There are a number of findings that are worth highlighting here. First, there is evidence that offshore funds indeed trade more aggressively than their onshore counterparts, judging from the average turnover (or more precisely, monthly average value of changes in the month-to-month positions, scaled by the funds' size). Second, there is no significant evidence to support the allegation that the offshore funds engage in positive feeding trading. In contrast, there is strong evidence that funds from the US and UK do exhibit a tendency to do so. Third, while offshore funds do herd, they do so far less than onshore funds from the US or UK.

In sum, the offshore funds are not especially worrisome monsters. 


\section{References}

Banerjee, Abhijit (1992), "A Simple Model of Herd Behavior.” Quarterly Journal of Economics 107, pp. 797-817.

Bekaert, Greet, and Campbell Harvey, 1998, "Capital Flows and the Behavior of Emerging Market Equity Returns," Working Paper, Duke University.

Bikhchandani, Sushil, David Hirshleifer, and Ivo Welch (1992), "A Theory of Fads, Fashion, Custom, and Cultural Change as Information Cascades." Journal of Political Economy 100, pp. 992-1020.

Brennan, M. J. and H. Cao, 1997, “International Portfolio Investment Flows," Journal of Finance 52: 1851-1880.

Brown, Stephen J., William N. Goetzmann, and Roger G. Ibbotson, 1999, “Offshore Hedge Funds: Survival and Performance, 1989-1995,” Journal of Business, 72(1), January.

Brown, Stephen J., William N. Goetzmann, and James Park, 1999, "Hedge Funds and the Asian Currency Crisis of 1997," forthcoming, Journal of Portfolio Management.

Choe, Hyuk, Bong-Chan Kho, and Rene M. Stulz (1998), "Do Foreign Investors Destabilize Stock Markets? The Korean Experience in 1997." NBER Working Paper No. 6661

De Long, J. Bradford, Andrei Shleifer, Lawrence H. Summers, and Robert J. Waldmann (1990), "Positive Feedback Investment Strategies and Destabilizing Rational Speculation." Journal of Finance, Vol. 45, No. 2, pp. 379-395.

Frankel, Jeffrey A. and Sergio L. Schmukler (1996), "Country Fund Discounts, Asymmetric Information and the Mexican Crisis of 1994: Did Local Residents Turn Pessimistic Before International Investors?” NBER Working Paper No. 5714.

Frankel, Jeffrey A. and Sergio L. Schmukler (1998), "Country Funds and Asymmetric Information.” Policy Research Working Paper No. 1886, The World Bank. Friedman, Milton (1953), “The Case for Flexible Exchange Rates," in Milton Friedman, ed. Essays in Positive Economics (University of Chicago Press, Chicago, IL).

Froot, Kenneth A., Paul G.J. O'Connell, and Mark S. Seasholes, (1998), "The Portfolio Flows of International Investors I." NBER Working Paper No. 6687. 
Grinblatt, Mark, Sheridan Titman, and Russ Wermers (1995), "Momentum Investment Strategies, Portfolio Performance, and Herding: A Study of Mutual Fund Behavior." American Economic Review Vol. 85, pp. 1088-1 105.

Helm, Robert W., 1997, “Offshore Investment Funds,” Chapter 17 in Clifford E. Kirsch, ed., The Financial Services Revolution: Understanding the Changing Role of Banks, Mutual Funds, and Insurance Companies, Chicago, London and Singapore: Irwin, 1997.

Henry, Peter, 1997, "Stock Market Liberalization, Economic Reform, and Emerging Market Equity Prices," Unpublished working paper, MIT.

Kahneman, Daniel and Amos Tversky (1979), "Prospect Theory: An Analysis of Decision Under Risk.” Econometrica 46, pp. 171-185.

Kim, Woochan, and Shang-Jin Wei, 1999, "Foreign Portfolio Investors Before and During a Crisis," NBER Working Paper 6968, February. [Also released as OECD Economics Department Working Paper No. 210, February, 1999.]

Lakonishok, Josef, Andrei Shleifer, and Robert Vishny (1992), "The Impact of Institutional Trading on Stock Prices.” Journal of Financial Economics Vol.32, pp. 2343.

Milroy, Robert, 1998, Standard \& Poor's Micropal Guide to Offshore Investment Funds - 1998-99 Edition. International Offshore Publications Limited, Guernsey, Channel Islands.

Scharfstein, David S. and Jeremy C. Stein (1990), "Herd Behavior and Investment." American Economic Review 80, pp.465-479.

Sharpe, William, 1995, "The Styles and Performances of Large Seasoned U.S. Mutual Funds, 1985-1994,” Working paper, Stanford University Business School. World Economic Forum (1998), The Global Competitiveness Report 1998. Geneva: Switzerland, 1988

Wermers, Russ (1995), "Herding, Trade Reversals, and Cascading by Institutional Investors.” Working Paper, University of Colorado Boulder.

Wylie, Samuel (1997), "Tests of the Accuracy of Measures of Herding." Unpublished Paper. 
Figure 1. Exchange Rate Level (US \$ per 1,000 Korea won)

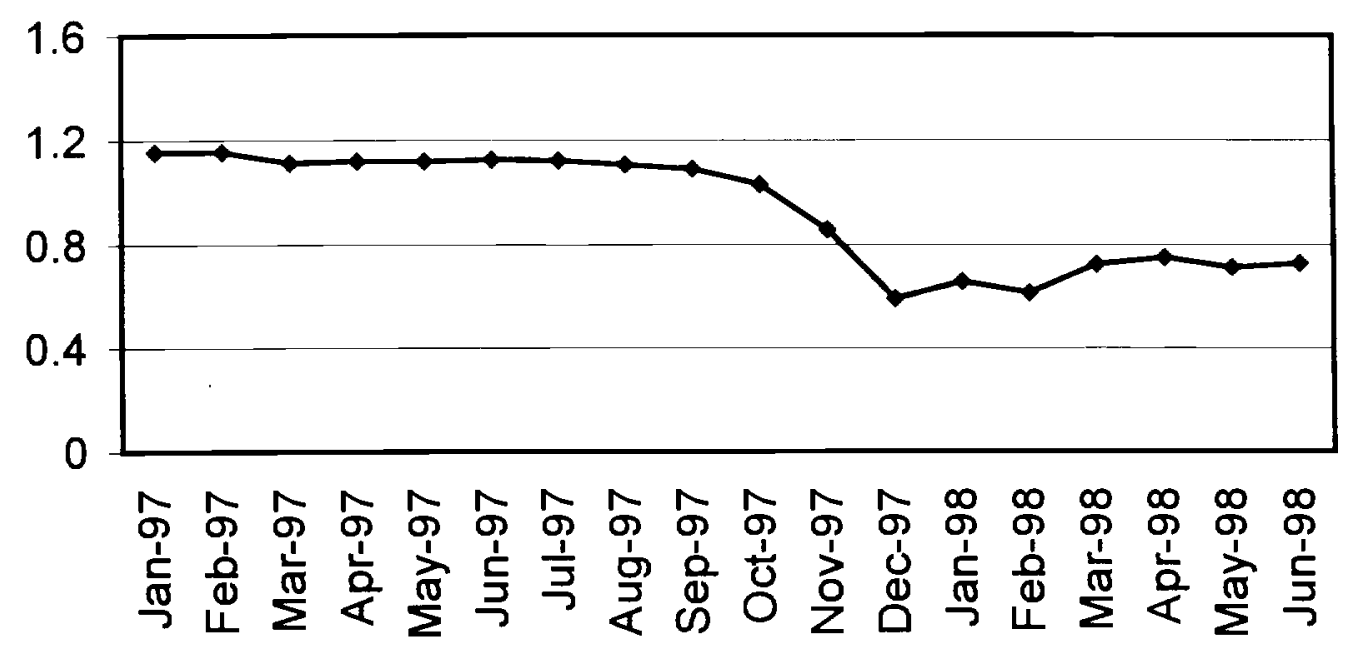

Figure 2. Stock Price Index (KOSPI, 1980=100)

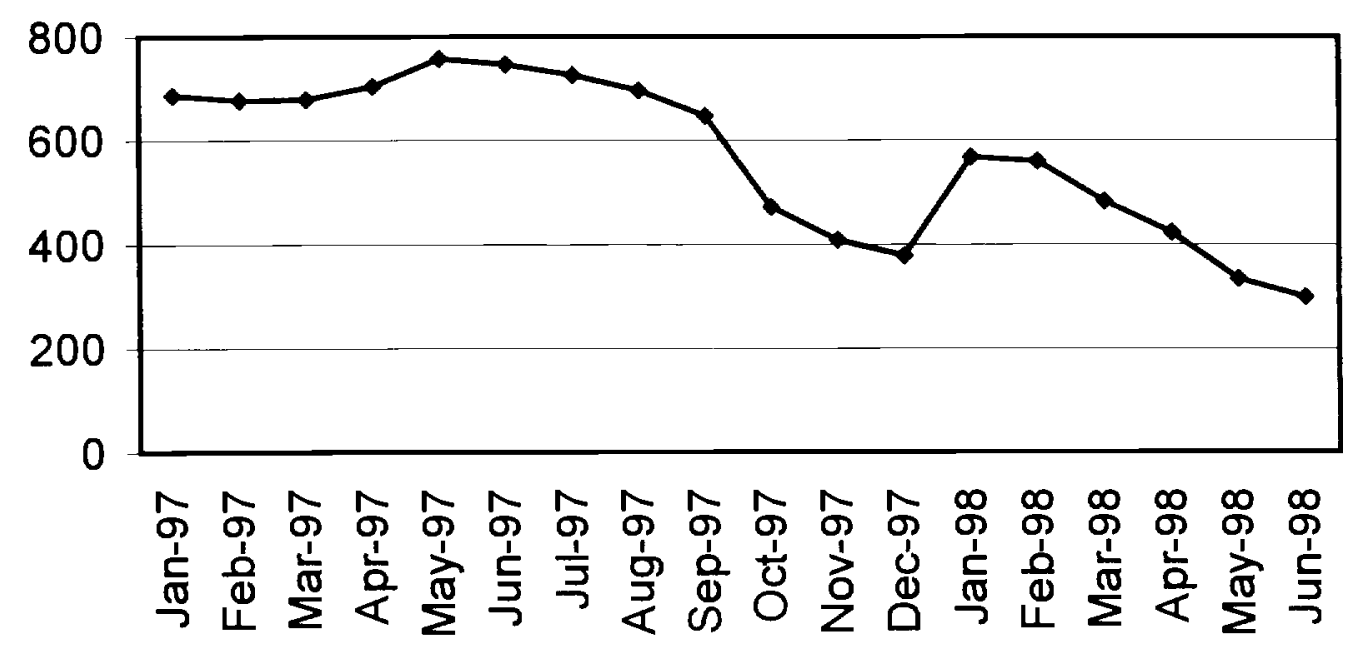


Figure 3. Current Value of US $\$ 100$

(Invested in KOSPI on January 1, 1997)

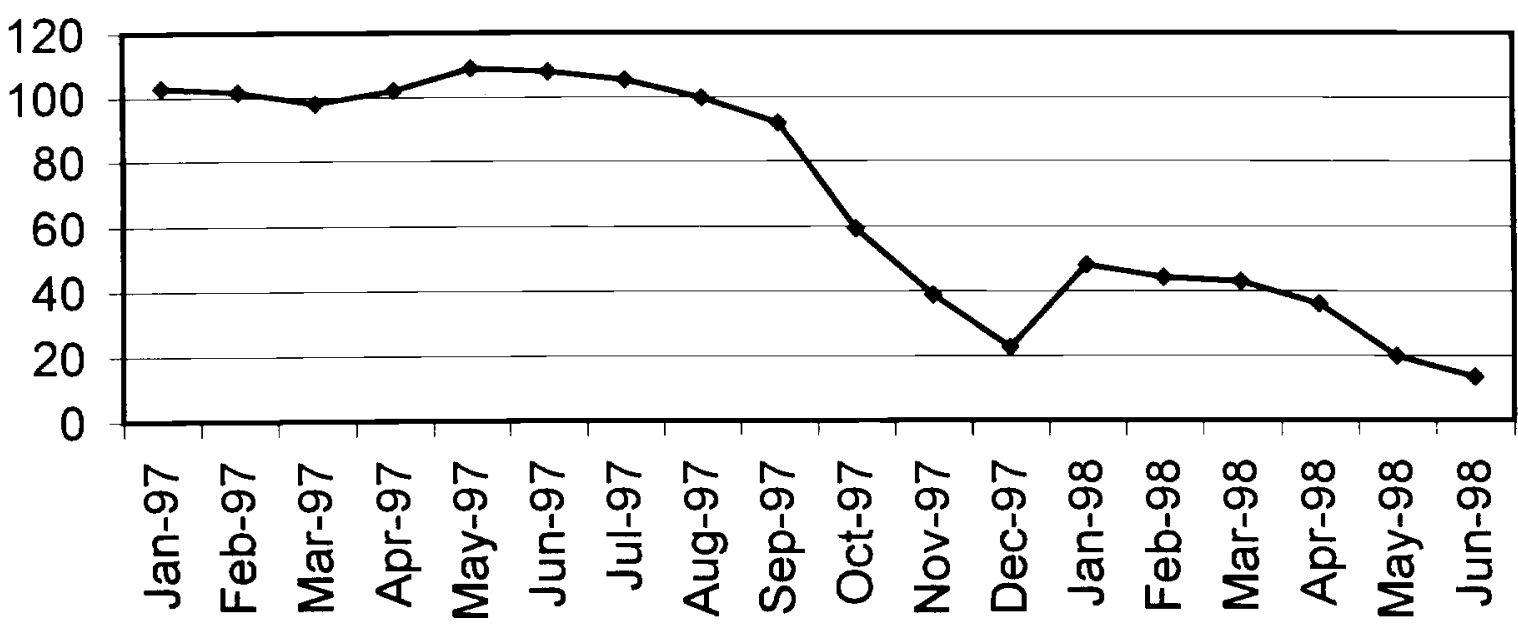

Figure 4. Total Market Value of Position by Domocile (Million U.S. Dollars)

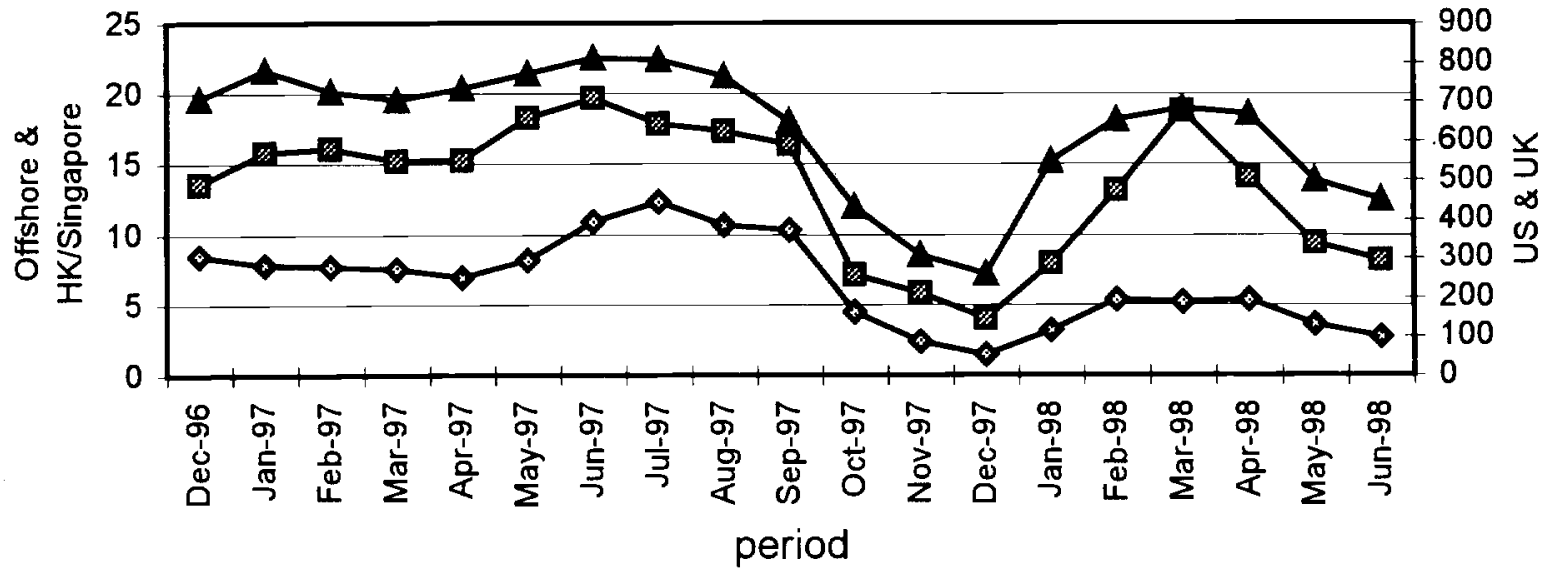

- Offshore Tax Havens $\longrightarrow$-HK \& Singapore $\rightarrow-$ US \& UK 
Table 1: Number of Foreign Investors by Origin

\begin{tabular}{|c|r|r|r|r|r|r|r|r|r|}
\hline & \multicolumn{3}{|c|}{ Offshore Tax Havens } & \multicolumn{3}{c|}{ US \& UK } & \multicolumn{3}{c|}{ HK \& Singapore } \\
\hline Date & \multicolumn{1}{|c|}{$\begin{array}{c}\text { No. of } \\
\text { Investors }\end{array}$} & $\begin{array}{c}\text { Average } \\
\text { Position } \\
\text { (bil won) }\end{array}$ & $\begin{array}{c}\text { Total } \\
\text { Position } \\
\text { (bil won) }\end{array}$ & $\begin{array}{c}\text { No. of } \\
\text { Investors }\end{array}$ & $\begin{array}{c}\text { Average } \\
\text { Position } \\
\text { (bil won) }\end{array}$ & $\begin{array}{c}\text { Total } \\
\text { Position } \\
\text { (bil won) }\end{array}$ & $\begin{array}{c}\text { No. of } \\
\text { Investors }\end{array}$ & $\begin{array}{c}\text { Average } \\
\text { Position } \\
\text { (bil won) }\end{array}$ & $\begin{array}{c}\text { Total } \\
\text { Position } \\
\text { (bil won) }\end{array}$ \\
\hline Dec.27, 96 & 58 & 1.59 & 92 & 683 & 6.54 & 4,464 & 31 & 1.33 & 41 \\
Nov.29, 97 & 41 & 1.07 & 44 & 484 & 6.09 & 2,947 & 22 & 0.64 & 14 \\
Jun.30,98 & 55 & 0.85 & 47 & 541 & 7.00 & 3,769 & 24 & 0.63 & 15 \\
\hline \hline
\end{tabular}

Note: The investors in the table include only portfolio investors who had registered with the Korea Securities Supervisory Board (KSSB) by December 31, 1996. 
Table 2. Trading Intensity

\begin{tabular}{|c|c|c|c|c|c|}
\hline \multirow[t]{2}{*}{ PANEL A } & \multicolumn{3}{|c|}{$\begin{array}{l}\text { Absolute value of changes in stock weights } \\
\text { (in terms of market value of positions) }\end{array}$} & \multicolumn{2}{|c|}{ Difference In Mean Test } \\
\hline & $\begin{array}{c}\text { (1) } \\
\text { Offshore Tax } \\
\text { Havens }\end{array}$ & $\begin{array}{c}(2) \\
\text { US \& UK }\end{array}$ & $\begin{array}{l}(3) \\
\text { HK \& Singapore }\end{array}$ & $(4)=(1)-(2)$ & $(5)=(1)-(3)$ \\
\hline (1) Whole Period & $\begin{array}{l}0.1497^{* *} \\
(0.0162) \\
\end{array}$ & $\begin{array}{l}0.1035^{* *} \\
(0.0040)\end{array}$ & $\begin{array}{l}0.1293^{* *} \\
(0.0183) \\
\end{array}$ & $\begin{array}{l}0.0462 * * \\
(0.0139) \\
\end{array}$ & $\begin{array}{c}0.0204 \\
(0.0268)\end{array}$ \\
\hline (2) Pre-Crisis Period & $\begin{array}{l}0.1331^{* *} \\
(0.0166)\end{array}$ & $\begin{array}{l}0.0960^{* *} \\
(0.0039)\end{array}$ & $\begin{array}{l}0.1094^{* *} \\
(0.0158)\end{array}$ & $\begin{array}{l}0.0370^{* *} \\
(0.0139)\end{array}$ & $\begin{array}{c}0.0237 \\
(0.0258)\end{array}$ \\
\hline (3) In-Crisis Period & $\begin{array}{l}0.1521^{* *} \\
(0.0188)\end{array}$ & $\begin{array}{l}0.1169^{* *} \\
(0.0060)\end{array}$ & $\begin{array}{l}0.1649 * * \\
(0.0317)\end{array}$ & $\begin{array}{l}0.0352^{*} \\
(0.0200)\end{array}$ & $\begin{array}{l}-0.0128 \\
(0.0348)\end{array}$ \\
\hline$(4)=(3)-(2)$ & $\begin{array}{c}0.0191 \\
(0.0250) \\
\end{array}$ & $\begin{array}{l}0.0209^{* *} \\
(0.0070) \\
\end{array}$ & $\begin{array}{c}0.0555 \\
(0.0345) \\
\end{array}$ & & \\
\hline \multirow[t]{2}{*}{ PANEL B } & \multicolumn{3}{|c|}{$\begin{array}{l}\text { Absolute value of changes in stock weights } \\
\text { (in terms of physical number of shares) }\end{array}$} & \multicolumn{2}{|c|}{ Difference In Mean Test } \\
\hline & $\begin{array}{c}\text { (1) } \\
\text { Offshore Tax } \\
\text { Havens } \\
\end{array}$ & $\begin{array}{c}(2) \\
\text { US \& UK }\end{array}$ & $\begin{array}{c}(3) \\
\text { HK \& Singapore }\end{array}$ & $(4)=(1)-(2)$ & $(5)=(1)-(3)$ \\
\hline (1) Whole Period & $\begin{array}{l}0.1213^{* *} \\
(0.0140)\end{array}$ & $\begin{array}{c}0.0800^{* *} \\
(0.0029) \\
\end{array}$ & $\begin{array}{l}0.1019^{* *} \\
(0.0140) \\
\end{array}$ & $\begin{array}{l}0.0413^{* *} \\
(0.0102) \\
\end{array}$ & $\begin{array}{c}0.0194 \\
(0.0225) \\
\end{array}$ \\
\hline (2) Pre-Crisis Period & $\begin{array}{l}0.1004^{* *} \\
(0.0131)\end{array}$ & $\begin{array}{c}0.0722^{* *} \\
(0.0028)\end{array}$ & $\begin{array}{l}0.0841^{* *} \\
(0.0124)\end{array}$ & $\begin{array}{l}0.0282^{* *} \\
(0.0101)\end{array}$ & $\begin{array}{c}0.0163 \\
(0.0203)\end{array}$ \\
\hline (3) In-Crisis Period & $\begin{array}{l}0.1322^{* *} \\
(0.0173)\end{array}$ & $\begin{array}{c}0.0928^{* *} \\
(0.0044)\end{array}$ & $\begin{array}{l}0.1283 * * \\
(0.0257)\end{array}$ & $\begin{array}{l}0.0394^{* *} \\
(0.0151)\end{array}$ & $\begin{array}{c}0.0039 \\
(0.0306)\end{array}$ \\
\hline$(4)=(3)-(2)$ & $\begin{array}{c}0.0318 \\
(0.0216) \\
\end{array}$ & $\begin{array}{c}0.0206^{* *} \\
(0.0051) \\
\end{array}$ & $\begin{array}{c}0.0442 \\
(0.0278)\end{array}$ & & \\
\hline
\end{tabular}

Notes:

(1) Standard errors are in the parentheses. ${ }^{* *}$ and ${ }^{*}$ denote significant at the $5 \%$ and $10 \%$ levels, respectively.

(2) The sample include only portfolio investors who had registered by December 31, 1997.

(3) Definition of trading intensity, TN:

$W(j, k, t) \equiv$ weight of stock $k$ in the total holdings by investor $j$ at the end of month $t$, either in terms of market value (panel A) or in terms of physical number of shares (panel B).

$$
\begin{aligned}
& T N(j, t)=\sum_{k}|W(j, k, t)-W(j, k, t-1)| \\
& T N(j)=\frac{1}{T-1} \sum_{t=2}^{T} T N(j, t) \\
& T N=\frac{1}{J} \sum_{j} T N(j)
\end{aligned}
$$




\section{Table 3. Positive Feedback Trading}

(Buyers' Ratio)

\begin{tabular}{|c|c|r|r|r|}
\hline & $\begin{array}{c}\text { Prior-Month } \\
\text { Performance }\end{array}$ & $\begin{array}{c}\text { Offshore } \\
\text { Tax Havens }\end{array}$ & US \& UK & HK \& Singapore \\
\hline Whole Period & $(01)-2.247 \sim-0.166$ & 0.4115 & 0.3916 & 0.4070 \\
& $(02)-0.166 \sim-0.067$ & 0.3536 & 0.3728 & 0.1515 \\
& $(03)-0.067 \sim 0.000$ & 0.3039 & 0.3956 & 0.2548 \\
& $(04) 0.000 \sim 0.092$ & 0.3434 & 0.4284 & 0.2879 \\
& $(05) 0.092 \sim 1.698$ & 0.4634 & 0.5024 & 0.4189 \\
\cline { 2 - 5 } & $(06)=(05)-(01)$ & $0.0519(0.0651)$ & $0.1108(0.0229)^{* *}$ & $0.0119(0.0853)$ \\
\hline Pre-Crisis Period & $(\mathrm{b} 01)-1.040 \sim-0.107$ & 0.3491 & 0.3607 & 0.2188 \\
& $(\mathrm{~b} 02)-0.107 \sim-0.047$ & 0.3474 & 0.3670 & 0.2738 \\
& $(\mathrm{~b} 03)-0.047 \sim 0.003$ & 0.3616 & 0.3875 & 0.2126 \\
& $(\mathrm{~b} 04)-0.003 \sim 0.069$ & 0.3405 & 0.4271 & 0.3618 \\
& $(\mathrm{~b} 05)-0.069 \sim 1.012$ & 0.4118 & 0.4733 & 0.4185 \\
\cline { 2 - 5 } & $(\mathrm{b} 06)=(\mathrm{b} 05)-(\mathrm{b} 01)$ & $0.0627(0.0818)$ & $0.1126(0.0312)^{* *}$ & $0.1997(0.1030)^{*}$ \\
\hline \multirow{5}{*}{ In-Crisis } & $(\mathrm{d} 01)-2.247 \sim-0.352$ & 0.4457 & 0.3654 & 0.5357 \\
& $(\mathrm{~d} 02)-0.349 \sim-0.138$ & 0.3923 & 0.4413 & 0.2813 \\
& $(\mathrm{~d} 03)-0.138 \sim-0.010$ & 0.2855 & 0.4027 & 0.2104 \\
& $(\mathrm{~d} 04)-0.010 \sim 0.149$ & 0.3004 & 0.4625 & 0.2217 \\
& $(\mathrm{~d} 05) 0.150 \sim 1.698$ & 0.5495 & 0.5272 & 0.4437 \\
\cline { 2 - 5 } & $(\mathrm{d} 06)=(\mathrm{d} 05)-(\mathrm{d} 01)$ & $0.1038(0.1098)$ & $0.1618(0.0376)^{* *}$ & $0.0920(0.1435)$ \\
\hline
\end{tabular}

Notes:

(1) Stock-months non-resident foreign institutions invest are divided into five groups according to prior-month return, defined as return in excess of the KOSPI return minus the won depreciation against the US dollar. For each return-group, the (equally-weighted) mean value of buyers' ratio $[=$ (no. of buyers - no. of sellers) / (no. of traders] is reported.

(2)

Within each investor group and sample period, difference in mean t-test is performed on the (equallyweighted) mean value of buyers' ratio stocks that are best and worst performers in the previous month. Standard errors are in the parentheses. ${ }^{* *}$ and ${ }^{*}$ indicate significant at the $5 \%$ and $10 \%$ levels, respectively. 
Table 4. Positive Feedback Trading

(Scale-Adjusted Net Purchase)

\begin{tabular}{|c|c|c|c|c|}
\hline & $\begin{array}{l}\text { Prior-Month } \\
\text { Performance }\end{array}$ & $\begin{array}{l}\text { Offshore } \\
\text { Tax Havens }\end{array}$ & $\overline{\text { US \& UK }}$ & HK \& Singapore \\
\hline \multirow[t]{6}{*}{ Whole Period } & (01) $-2.247 \sim-0.166$ & -0.2103 & -0.2038 & -0.1496 \\
\hline & (02) $-0.166 \sim-0.067$ & -0.3053 & -0.2663 & -0.6909 \\
\hline & (03) $-0.067 \sim 0.000$ & -0.3998 & -0.2241 & -0.4850 \\
\hline & (04) $0.000 \sim 0.092$ & -0.3170 & -0.1292 & -0.3886 \\
\hline & (05) $0.092 \sim 1.698$ & -0.0994 & -0.0049 & -0.1769 \\
\hline & $(06)=(05)-(01)$ & $0.1109(0.1354)$ & $0.1989(0.0487)^{* *}$ & $-0.0274(0.1775)$ \\
\hline \multirow[t]{6}{*}{ Pre-Crisis Period } & (b01) $-1.040 \sim-0.107$ & -0.3085 & -0.2944 & -0.5276 \\
\hline & (b02) $-0.107 \sim-0.047$ & -0.3061 & -0.3003 & -0.4459 \\
\hline & (b03) $-0.047 \sim 0.003$ & -0.3056 & -0.2484 & -0.5943 \\
\hline & (b04) $0.003 \sim 0.069$ & -0.2825 & -0.1381 & -0.2228 \\
\hline & $(\mathrm{b} 05) \quad 0.069 \sim 1.012$ & -0.2336 & -0.0506 & -0.1159 \\
\hline & $(b 06)=(b 05)-(b 01)$ & $0.0750(0.1664)$ & $0.2438(0.0654)^{* *}$ & $0.4116(0.2136)^{*}$ \\
\hline \multirow[t]{6}{*}{ In-Crisis } & $(\mathrm{d} 01)-2.247 \sim-0.352$ & -0.1704 & -0.2429 & 0.0504 \\
\hline & $(\mathrm{d} 02)-0.349 \sim-0.138$ & -0.2285 & -0.0909 & -0.3789 \\
\hline & $(\mathrm{d} 03)-0.138 \sim-0.010$ & -0.4711 & -0.1950 & -0.5467 \\
\hline & $(\mathrm{d} 04)-0.010 \sim 0.149$ & -0.4121 & -0.0617 & -0.5718 \\
\hline & $(d 05) \quad 0.150 \sim 1.698$ & 0.1000 & 0.0404 & -0.1876 \\
\hline & $(d 06)=(d 05)-(d 01)$ & $0.2704(0.2309)$ & $0.2834(0.0809)^{* *}$ & $-0.2381(0.2976)$ \\
\hline
\end{tabular}

Note: Please see the footnotes to Table 3. 
Table 5. Flight to Large-Sized Stocks

(Buyers' Ratio)

\begin{tabular}{|c|c|c|c|c|c|c|}
\hline & & & $\begin{array}{l}\text { Prior-Month } \\
\text { Performance }\end{array}$ & Small & Medium & Large \\
\hline \multirow[t]{18}{*}{ Pre-Crisis } & \multirow{6}{*}{$\begin{array}{c}\text { Offshore } \\
\text { Tax } \\
\text { Havens }\end{array}$} & All & & 0.0000 & 0.4000 & 0.4011 \\
\hline & & $(\mathrm{b} 01)-2$ & $2.247 \sim-0.166$ & 0.0000 & 0.6154 & 0.2588 \\
\hline & & $(\mathrm{b} 02)-0$ & $-0.166 \sim-0.067$ & 0.0000 & 0.2500 & 0.4216 \\
\hline & & $(\mathrm{b} 03)-0$ & $-0.067 \sim 0.000$ & 0.0000 & 0.5000 & 0.3916 \\
\hline & & (b04) 0 & $0.000 \sim 0.092$ & 0.0000 & 0.0000 & 0.3846 \\
\hline & & (b05) 0 & $0.092 \sim 1.698$ & 0.0000 & 0.3077 & 0.5347 \\
\hline & \multirow[t]{6}{*}{ US \& UK } & All & & 0.4242 & 0.4080 & 0.4798 \\
\hline & & (b07) -1 & $-1.040 \sim-0.107$ & 0.4706 & 0.4565 & 0.3627 \\
\hline & & (b08) -c & $-0.107 \sim-0.047$ & 0.3800 & 0.3133 & 0.4459 \\
\hline & & (b09) -c & $-0.047 \sim 0.003$ & 0.2857 & 0.4510 & 0.4661 \\
\hline & & (b10) 0 & $0.003 \sim 0.069$ & 0.4375 & 0.4420 & 0.5148 \\
\hline & & (b11) 0 & $0.069 \sim 1.012$ & 0.4853 & 0.3860 & 0.5874 \\
\hline & \multirow{6}{*}{$\begin{array}{c}\text { HK \& } \\
\text { Singapore }\end{array}$} & All & & 0.0667 & 0.2500 & 0.3548 \\
\hline & & (b13) -2 & $-2.247 \sim-0.352$ & 0.3333 & 0.4286 & 0.0930 \\
\hline & & (b14) $-c$ & $-0.349 \sim-0.138$ & 0.0000 & 0.0000 & 0.4167 \\
\hline & & (b15) -c & $-0.138 \sim-0.010$ & 0.0000 & 0.3333 & 0.3492 \\
\hline & & (b16) -c & $-0.010 \sim 0.149$ & 0.0000 & 0.6667 & 0.3409 \\
\hline & & (b17) 0 & $0.150 \sim 1.698$ & 0.0000 & 0.1111 & 0.5400 \\
\hline \multirow[t]{18}{*}{ In-Crisis } & \multirow{6}{*}{$\begin{array}{c}\text { Offshore } \\
\text { Tax } \\
\text { Havens }\end{array}$} & All & & 0.2500 & 0.1290 & 0.5376 \\
\hline & & $(\mathrm{d} 01)-2$ & $-2.247 \sim-0.166$ & 0.0000 & 0.0000 & 0.7660 \\
\hline & & (d02) $-\mathrm{C}$ & $-0.166 \sim-0.067$ & 1.0000 & 0.0000 & 0.4714 \\
\hline & & $(d 03)-1$ & $-0.067 \sim 0.000$ & 0.3333 & 0.0000 & 0.5094 \\
\hline & & (d04) 0 & $0.000 \sim 0.092$ & 0.0000 & 0.1429 & 0.4276 \\
\hline & & (d05) 0 & $0.092 \sim 1.698$ & -- & 0.7500 & 0.6257 \\
\hline & \multirow[t]{6}{*}{ US \& UK } & All & & 0.3681 & 0.4751 & 0.5559 \\
\hline & & $(d 07)-1$ & $-1.040 \sim-0.107$ & 0.3077 & 0.4593 & 0.6567 \\
\hline & & $(d 08)-c$ & $-0.107 \sim-0.047$ & 0.3690 & 0.4479 & 0.5275 \\
\hline & & $(d 09)-c$ & $-0.047 \sim 0.003$ & 0.2586 & 0.3630 & 0.5372 \\
\hline & & $(d \mid 0)$ & $0.003 \sim 0.069$ & 0.2909 & 0.5000 & 0.5075 \\
\hline & & $(\mathrm{d} 11)$ & $0.069 \sim 1.012$ & 0.6491 & 0.6356 & 0.5971 \\
\hline & \multirow{6}{*}{$\begin{array}{c}\text { HK \& } \\
\text { Singapore }\end{array}$} & All & & -- & 0.0000 & 0.4043 \\
\hline & & $(\mathrm{d} 13)-2$ & $-2.247 \sim-0.352$ & -- & 0.0000 & 0.6800 \\
\hline & & $(d 14)-c$ & $-0.349 \sim-0.138$ & -- & 0.0000 & 0.3182 \\
\hline & & $(d 15)-($ & $-0.138 \sim-0.010$ & - & 0.0000 & 0.2987 \\
\hline & & $(d 16)-($ & $-0.010 \sim 0.149$ & - & -- & 0.3012 \\
\hline & & (d17) & $0.150 \sim 1.698$ & - & -- & 0.5714 \\
\hline
\end{tabular}

Notes

(1) Note that sub-categories do not add up exactly with the upper-category. This is because observations (stockmonth) not initially owned by the investor group are excluded from the sample (see the justification in the text) and this exclusion is not universal over all investor groups.

(2) - denotes no active traders. 0.0000 implies that all active traders are sellers. 
Table 6. Ex-Post Profitability of Positive Feedback Trading

\begin{tabular}{|c|c|c|c|c|c|c|c|c|}
\hline \multicolumn{9}{|c|}{ Whole Sample Period } \\
\hline \multirow{2}{*}{$\begin{array}{c}\text { Investment } \\
\text { Horizon }\end{array}$} & \multicolumn{4}{|c|}{ Returns of 10 Best \& Worst Performers } & \multicolumn{4}{|c|}{ Returns of 30 Best \& Worst Performers } \\
\hline & Best & Worst & Difference & s.e. & Best & Worst & Difference & s.e. \\
\hline-1 & 0.4251 & -0.5283 & $0.9534^{* *}$ & 0.0382 & 0.2883 & -0.3880 & $0.6763 * *$ & 0.0170 \\
\hline 1 & -0.0824 & -0.0059 & $-0.0765 * *$ & 0.0357 & -0.0855 & -0.0119 & $-0.0736^{* *}$ & 0.0183 \\
\hline 2 & -0.1721 & -0.0803 & $-0.0918^{*}$ & 0.0530 & $-0,1524$ & -0.0795 & $-0.0729 * *$ & 0.0255 \\
\hline 3 & -0.2435 & -0.1219 & $-0.1216^{* *}$ & 0.0584 & -0.2165 & -0.1154 & $-0.1011 * *$ & 0.0304 \\
\hline 4 & -0.3308 & -0.1793 & $-0.1515 * *$ & 0.0669 & -0.2820 & -0.1716 & $-0.1104 * *$ & 0.0334 \\
\hline 5 & -0.3808 & -0.2562 & $-0.1246^{*}$ & 0.0728 & -0.3234 & -0.2396 & $-0.0838^{* *}$ & 0.0375 \\
\hline 6 & -0.4409 & -0.3334 & -0.1075 & 0.0779 & -0.3328 & -0.3879 & 0.0551 & 0.0408 \\
\hline \multicolumn{9}{|c|}{ Pre-Crisis Period } \\
\hline Investment & \multicolumn{4}{|c|}{ Returns of 10 Best \& Worst Performers } & \multicolumn{4}{|c|}{ Returns of 30 Best \& Worst Performers } \\
\hline Horizon & Best & Worst & Difference & s.e. & Best & Worst & Difference & s.e. \\
\hline-1 & 0.3873 & -0.3062 & $0.6936^{* *}$ & 0.0182 & 0.2658 & -0.2366 & $0.5024^{* *}$ & 0.0091 \\
\hline 1 & -0.0775 & -0.0372 & -0.0403 & 0.0348 & -0.0724 & -0.0178 & $-0.0546^{* *}$ & 0.0174 \\
\hline 2 & -0.1600 & -0.1920 & 0.0320 & 0.0637 & -0.1614 & -0.1446 & -0.0168 & 0.0314 \\
\hline 3 & -0.2467 & -0.2365 & -0.0102 & 0.0720 & -0.2513 & -0.1924 & -0.0590 & 0.0392 \\
\hline 4 & -0.3925 & -0.3439 & -0.0486 & 0.0863 & -0.3581 & -0.2973 & -0.0608 & 0.0445 \\
\hline 5 & -0.4672 & -0.4313 & -0.0359 & 0.0965 & -0.4298 & -0.3574 & -0.0725 & 0.0494 \\
\hline 6 & -0.5219 & -0.5064 & -0.0155 & 0.0960 & -0.5039 & -0.4462 & -0.0577 & 0.0507 \\
\hline \multicolumn{9}{|c|}{ In-Crisis Period } \\
\hline Investment & \multicolumn{4}{|c|}{ Returns of 10 Best \& Worst Performers } & \multicolumn{4}{|c|}{ Returns of 30 Best \& Worst Performers } \\
\hline Horizon & Best & Worst & Difference & s.e. & Best & Worst & Difference & s.e. \\
\hline-1 & 0.4765 & -0.5460 & $1.0226^{* *}$ & 0.0380 & 0.3163 & -0.3897 & $0.7060^{* *}$ & 0.0163 \\
\hline 1 & -0.1057 & -0.0103 & $-0.0954 * * *$ & 0.0323 & -0.0983 & -0.0181 & $-0.0802 * *$ & 0.0165 \\
\hline 2 & -0.1897 & -0.0683 & $-0.1215^{* *}$ & 0.0503 & -0.1635 & -0.0724 & $-0.0911 * *$ & 0.0241 \\
\hline 3 & -0.2427 & -0.1170 & $-0.1257^{* *}$ & 0.0558 & -0.2139 & -0.1118 & $-0.1021 * *$ & 0.0290 \\
\hline 4 & $-0,3308$ & -0.1793 & $-0.1515^{* *}$ & 0.0669 & -0.2820 & -0.1716 & $-0.1104^{* *}$ & 0.0334 \\
\hline 5 & -0.3808 & -0.2562 & $-0.1246^{*}$ & 0.0728 & $\begin{array}{l}-0.3234 \\
\end{array}$ & $\begin{array}{l}-0.2396 \\
\end{array}$ & $-0.0838 * *$ & 0.0375 \\
\hline 6 & -0.4409 & -0.3334 & -0.1075 & 0.0779 & -0.3879 & -0.3328 & -0.0551 & 0.0408 \\
\hline
\end{tabular}

Notes:

(1) We form portfolios of best and worst performers based on previous month excess returns (reported in the rows labeled as "horizon -1"), and then track their relative performances in the subsequent six months (reported in rows labeled as "horizons 1-6"). We constrain the sample to those that three investor groups trade on.

(2) The return (for a given stock) is defined as $\left(\ln P_{t}-\ln P_{t-1}\right)-\left(\ln K_{t}-\ln K_{t-1}\right)-\left(S_{t}-S_{t+1}\right)$, where $P_{t}$ is stock price, $K_{t}$ is KOSPI market index, and $S_{\imath}$ is spot exchange rate (won/US dollar). Since price data is available only up to October 1998 , the computations are constrained accordingly. ${ }^{* *}$ and ${ }^{*}$ denote significant at the $5 \%$ and $10 \%$ levels, respectively. 


\section{Table 7a. Herding}

\begin{tabular}{||l|c|c|c|c|c|}
\hline \hline & \multicolumn{3}{|c|}{ LSV Herding Index } & \multicolumn{2}{c|}{ Difference In Mean Test } \\
\hline & $\begin{array}{c}(1) \\
\text { Offshore Tax } \\
\text { Havens }\end{array}$ & US \& UK & $\begin{array}{c}(2) \\
\text { HK \& } \\
\text { Singapore }\end{array}$ & $(4)=(1)-(2)$ & $(5)=(1)-(3)$ \\
& $0.0455^{* *}$ & $0.0683^{* *}$ & 0.0202 & $-0.0228^{*}$ & 0.0253 \\
& $(0.0101)[260]$ & $(0.0042)[1,846]$ & $(0.0150)[114]$ & $(0.0119)$ & $(0.0182)$ \\
\hline (1) Whole Period & $0.0423^{* *}$ & $0.0861^{* *}$ & 0.0173 & $-0.0439^{* *}$ & 0.0250 \\
& $(0.0142)[140]$ & $(0.0054)[1,036]$ & $(0.0206)[47]$ & $(0.0155)$ & $(0.0273)$ \\
\hline (2) Pre-Crisis Period & $0.0493^{* *}$ & $0.0456^{* *}$ & 0.0223 & 0.0037 & 0.0270 \\
& $(0.0144)[120]$ & $(0.0067)[810]$ & $(0.0211)[67]$ & $(0.0182)$ & $(0.0249)$ \\
\hline$(3)$ In-Crisis Period & -0.0070 & $-0.0406^{* *}$ & 0.0050 & & \\
\hline$(4)=(3)-(2)$ & $(0.0204)$ & $(0.0085)$ & $(0.0306)$ & & \\
& \multicolumn{3}{|l}{$-(2)$} \\
\hline
\end{tabular}

Notes:

(1) Standard errors are in the parentheses, while numbers of observations are in the square brackets. ** and * denote significant at the $5 \%$ and $10 \%$ levels, respectively.

Table $7 \mathrm{~b}$. Herding

(Excluding stock-months in which there is a change in quantity of outstanding shares)

\begin{tabular}{|c|c|c|c|c|c|}
\hline & \multicolumn{3}{|c|}{ LSV Herding Index } & \multicolumn{2}{|c|}{ Difference In Mean Test } \\
\hline & $\begin{array}{c}(1) \\
\text { Offshore Tax } \\
\text { Havens } \\
\end{array}$ & $\begin{array}{c}\text { (2) } \\
\text { US \& UK }\end{array}$ & $\begin{array}{c}\text { (3) } \\
\text { HK \& } \\
\text { Singapore }\end{array}$ & $(4)=(1)-(2)$ & $(5)=(1)-(3)$ \\
\hline (1) Whole Period & $\begin{array}{c}0.0314^{* *} \\
(0.0105)[219]\end{array}$ & $\begin{array}{c}0.0533^{* *} \\
(0.0044)[1,620]\end{array}$ & $\begin{array}{c}0.0010 \\
(0.0135)[100]\end{array}$ & $\begin{array}{l}-0.0219^{*} \\
(0.0127)\end{array}$ & $\begin{array}{l}0.0304^{*} \\
(0.0181)\end{array}$ \\
\hline (2) Pre-Crisis Period & $\begin{array}{c}0.0268^{*} \\
(0.0141)[123]\end{array}$ & $\begin{array}{c}0.0709^{* *} \\
(0.0057)[880]\end{array}$ & $\begin{array}{c}0.0006 \\
(0.0187)[40]\end{array}$ & $\begin{array}{c}-0.0441^{* *} \\
(0.0162)\end{array}$ & $\begin{array}{c}0.0262 \\
(0.0269) \\
\end{array}$ \\
\hline (3) In-Crisis Period & $\begin{array}{c}0.0373^{* *} \\
(0.0159)[96]\end{array}$ & $\begin{array}{c}0.0323^{* *} \\
(0.0069)[740]\end{array}$ & $\begin{array}{c}0.0012 \\
(0.0189)[60]\end{array}$ & $\begin{array}{c}0.0050 \\
(0.0199)\end{array}$ & $\begin{array}{c}0.0361 \\
(0.0251)\end{array}$ \\
\hline$(4)=(3)-(2)$ & $\begin{array}{c}0.0105 \\
(0.0213)\end{array}$ & $\begin{array}{c}-0.0385^{* *} \\
(0.0089)\end{array}$ & $\begin{array}{c}0.0006 \\
(0.0277)\end{array}$ & & \\
\hline
\end{tabular}

Notes: During the sample period, there were 601 occasions (stock months) on which the quantity of outstanding shares increased and 2 occasions on which the outstanding shares declined. 
Table 8. Ex-Post Profitability on Herding (Net Purchase)

\begin{tabular}{|c|c|c|c|c|c|}
\hline & \multicolumn{3}{|c|}{ One Month Investment Horizon } & \multicolumn{2}{|c|}{ Three Month Investment Horizon } \\
\hline & & $\beta_{0}$ & $\beta_{1}$ & $\beta_{0}$ & $\beta_{1}$ \\
\hline \multirow[t]{3}{*}{ Whole Period } & Offshore Tax Havens & $\begin{array}{c}0.0360 \\
(0.0254)\end{array}$ & $\begin{array}{c}-0.1971^{*} \\
(0.1143)\end{array}$ & $\begin{array}{c}0.0050 \\
(0.0354)\end{array}$ & $\begin{array}{c}0.0819 \\
(0.1615)\end{array}$ \\
\hline & US \& UK & $\begin{array}{c}-0.0014 \\
(0.0087)\end{array}$ & $\begin{array}{c}0.0467 \\
(0.0388)\end{array}$ & $\begin{array}{c}0.0046 \\
(0.0131) \\
\end{array}$ & $\begin{array}{c}0.0535 \\
(0.0582)\end{array}$ \\
\hline & HK \& Singapore & $\begin{array}{c}0.0192 \\
(0.0299)\end{array}$ & $\begin{array}{c}-0.1663 \\
(0.1379)\end{array}$ & $\begin{array}{c}0.0079 \\
(0.0380) \\
\end{array}$ & $\begin{array}{c}0.0914 \\
(0.1850)\end{array}$ \\
\hline \multirow[t]{3}{*}{ Pre-Crisis Period } & Offshore Tax Havens & $\begin{array}{c}-0.0112 \\
(0.0223)\end{array}$ & $\begin{array}{c}0.0133 \\
(0.1024)\end{array}$ & $\begin{array}{c}0.0003 \\
(0.0365)\end{array}$ & $\begin{array}{c}-0.0293 \\
(0.1684)\end{array}$ \\
\hline & US \& UK & $\begin{array}{c}0.0015 \\
(0.0085)\end{array}$ & $\begin{array}{c}0.0046 \\
(0.0380)\end{array}$ & $\begin{array}{c}0.0028 \\
(0.0139)\end{array}$ & $\begin{array}{c}0.0180 \\
(0.0622)\end{array}$ \\
\hline & HK \& Singapore & $\begin{array}{c}-0.0347 \\
(0.0409)\end{array}$ & $\begin{array}{c}0.0950 \\
(0.1997)\end{array}$ & $\begin{array}{c}-0.0210 \\
(0.0576)\end{array}$ & $\begin{array}{c}0.2354 \\
(0.3262)\end{array}$ \\
\hline \multirow[t]{3}{*}{ In-Crisis Period } & Offshore Tax Havens & $\begin{array}{c}0.0742 \\
(0.0530)\end{array}$ & $\begin{array}{c}-0.3757^{*} \\
(0.2249)\end{array}$ & $\begin{array}{c}0.0653 \\
(0.0651)\end{array}$ & $\begin{array}{c}0.1584 \\
(0.2837)\end{array}$ \\
\hline & US \& UK & $\begin{array}{c}-0.0025 \\
(0.0165)\end{array}$ & $\begin{array}{c}0.0969 \\
(0.0739)\end{array}$ & $\begin{array}{c}0.0100 \\
(0.0236)\end{array}$ & $\begin{array}{c}0.0863 \\
(0.1048)\end{array}$ \\
\hline & HK \& Singapore & $\begin{array}{c}0.0275 \\
(0.0452)\end{array}$ & $\begin{array}{c}-0.2039 \\
(0.1965)\end{array}$ & $\begin{array}{c}-0.0246 \\
(0.0558)\end{array}$ & $\begin{array}{c}0.1307 \\
(0.2426)\end{array}$ \\
\hline
\end{tabular}

Note:

$R_{k+1}=\alpha+\alpha_{k}+\alpha_{t}+\left(\beta_{0}+\beta_{1} H_{k}\right) N P_{k}+\varepsilon_{k}$

where $R_{k+1}$ is the return from to $t+1$ on stock $j ; \alpha_{1}$, Month dummy; $\alpha_{k}$, Industry dummy; $H_{k}$, Herding index at time $t$ for stock $j ; N P_{\mu}$, Scale adjusted net purchase at time $t$ for stock $j$. 